EPJ Web of Conferences 24, 05001 (2012)

DOI: $10.1051 /$ epjconf/20122405001

(c) Owned by the authors, published by EDP Sciences - SIF, 2012

\title{
Vertical distribution of natural radionuclides in soils
}

\author{
P. Blanco Rodríguez ${ }^{1}$, F. Vera Tomé ${ }^{1, *}$ and J. C. Lozano ${ }^{2}$
}

${ }^{1}$ Natural Radioactivity Group, Universidad de Extremadura

Avd. Elvas s/n, 06071 Badajoz, Spain

2 Laboratorio de Radiaciones Ionizantes, Facultad de Ciencias

Universidad de Salamanca - 37008 Salamanca, Spain

\begin{abstract}
Low-level alpha spectrometry techniques using semiconductor detectors (PIPS) and liquid scintillation counters (LKB Quantulus $1220^{\mathrm{TM}}$ ) were used in order to determine the activity concentration of ${ }^{238} \mathrm{U},{ }^{232} \mathrm{Th},{ }^{234} \mathrm{U},{ }^{230} \mathrm{Th},{ }^{226} \mathrm{Ra}$, and ${ }^{210} \mathrm{~Pb}$ in soil samples. The soils were collected from an old disused uranium mine located in southwest Spain. The soils were selected with different levels of influence from the installation, in such a way that they had different levels of radioactive contamination. The vertical profiles in the soils (down to $40 \mathrm{~cm}$ depth) were studied in order to evaluate the vertical distribution of the natural radionuclides. The possible contamination of subsurface waters depends strongly on vertical migration, and the transfer to plants (herbs, shrubs, and trees) also will depend on the distribution of the radionuclides in the root zone. The study of the activity ratios between radionuclides belonging to the same series allowed us to assess the differing behaviour of the radionuclides involved. The vertical profiles for these radionuclides were different at each sampling point, showing the local impact of the installation. However, the profiles per point were similar for the long-lived radionuclides of the ${ }^{238} \mathrm{U}$ series $\left({ }^{238} \mathrm{U}\right.$, ${ }^{234} \mathrm{U},{ }^{230} \mathrm{Th}$, and ${ }^{226} \mathrm{Ra}$ ). Also, a major disequilibrium was observed between ${ }^{210} \mathrm{~Pb}$ and ${ }^{226} \mathrm{Ra}$ in the surface layer, due to ${ }^{222} \mathrm{Rn}$ emanation and subsequent surface deposition of ${ }^{210} \mathrm{~Pb}$.
\end{abstract}

${ }^{*}$ E-mail: fvt@unex.es

This is an Open Access article distributed under the terms of the Creative Commons Attribution License 2.0, which permits unrestricted use, distribution, and reproduction in any medium, provided the original work is properly cited. 


\section{Study area}

Soil sampling was carried out in the "Los Ratones" mine, located in the Region of Extremadura in the south-west of Spain. This installation, with an area of $2.3 \mathrm{~km}^{2}$, was in production from 1960 to 1974 . Afterwards, it was inactive for several years, and finally restoration work was performed (1998-1999). More details about the characteristics of this mine, as well as other studies of interest performed in this area are given elsewhere $([1-3])$.

\section{Materials and methods}

\subsection{Sampling and sample preparation}

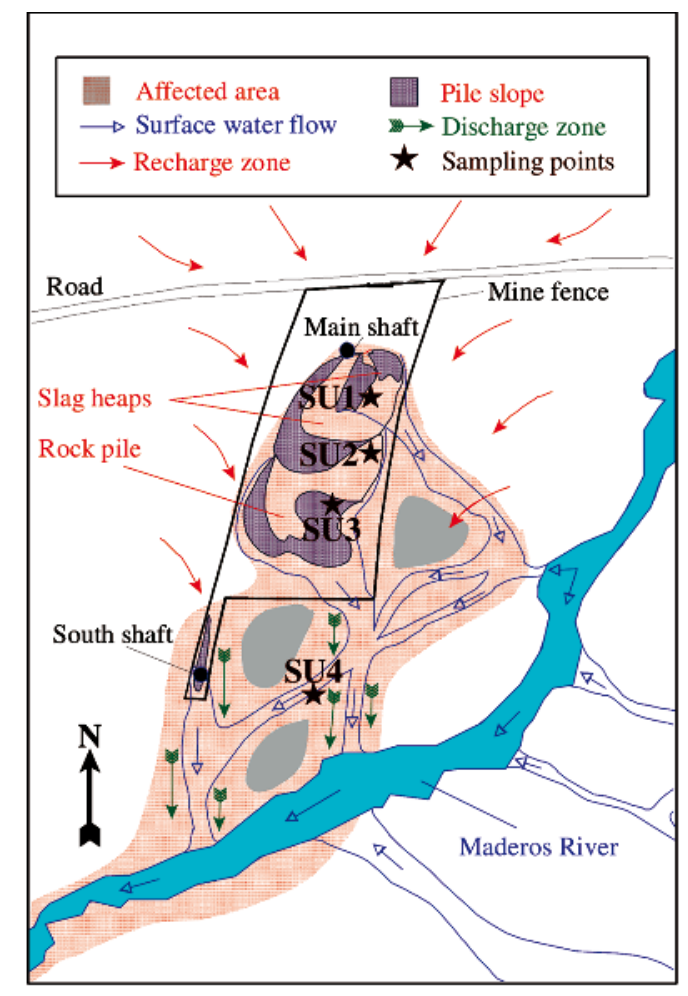

Fig. 1: Map of the study zone in which the mine is located. The major topographic features and the sampling points are marked.

Four sampling sites were chosen along a thalweg of the moisture gradient (fig. 1). The soil sampling was done with an EIJKELKAMP split-tube 
sampler. This sampler reaches $40 \mathrm{~cm}$ in depth. Once sampled, the $40 \mathrm{~cm}$ soil core was frozen and four subsamples of $10 \mathrm{~cm}$ each were extracted.

Sample digestion prior to the radiochemical assay was performed by acid digestion under pressure in a microwave oven (Millestone Mod. Ethos 900).

The analysis of major elements for the samples once digested was carried out by ICP-OES (Yobin-Ivon Mod. Ultima II).

\subsection{Radiochemical methods and measurement techniques}

The activity concentrations of the uranium, thorium, and radium isotopes in the different soil fractions were determined by alpha-spectrometry with PIPS semiconductor detectors of $450 \mathrm{~mm}^{2}$ active area. For the uranium and thorium isotopes, chemical separation using tri-n-butyl phosphate (TBP), and further thorium purification by anionic exchange resin [4], was followed by electrodeposition to form the high-resolution alpha sources [5]. The method used for the determination of radium was based on chemical purification by co-precipitation of $\mathrm{PbSO}_{4} / \mathrm{BaSO}_{4}$, and the subsequent source preparation by microprecipitation of $\mathrm{Ba}(\mathrm{Ra}) \mathrm{SO}_{4}$ [6]. The activity concentration of ${ }^{210} \mathrm{~Pb}$ was determined by liquid scintillation counting (LSC) [7]. An LKB Quantulus $1220^{\mathrm{TM}}$ spectrometer was used for the LSC measurements.

\section{Results and discussion}

Figure 2 shows the results. For ${ }^{238} \mathrm{U}$ (similar profiles were obtained for ${ }^{234} \mathrm{U}$ ), the greatest concentrations were observed in the surface soil, especially at the point SU4 probably due to the greater impact from the installation. The activity concentration decreases with increasing depth, showing that there is a surface input of this radionuclide followed by transport in depth. A dynamic model compatible with the observed profile would be one of constant leaching rate, resulting in an exponential profile.

The ${ }^{230} \mathrm{Th}$ profile shows a clear surface contribution at the point SU4, where the activity concentrations are much higher in the surface layer than in the deeper layers. Although at a different scale, it is interesting to note that the profiles observed for ${ }^{230} \mathrm{Th}$ are very similar to those for ${ }^{226} \mathrm{Ra}$. In spite of the latter being a decay product of the thorium isotope, one would expect their physicochemical characteristics in the soil to be very different.

For ${ }^{210} \mathrm{~Pb}$, the greatest concentrations at all the sampling points were in the surface layer. The observed profile is indicative of a one-off deposition event, which could be attributable to deposition of suspended lead probably caused by surface work carried out in some short period during the operation 

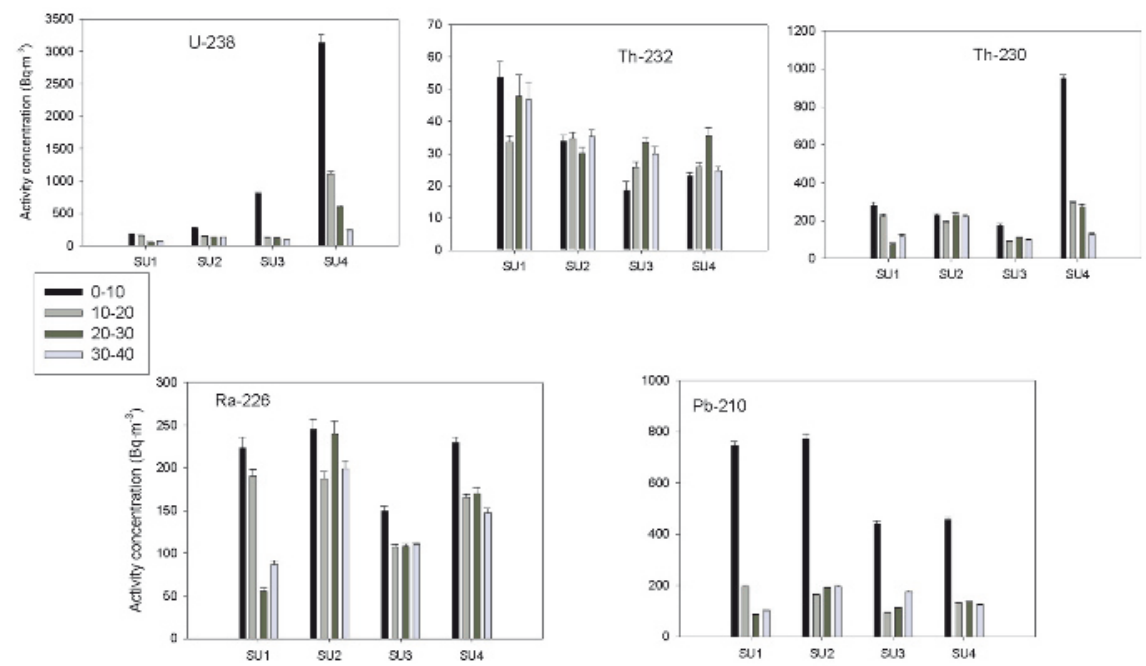

Fig. 2: Activity concentration of radionuclides studied at the four sampling points $(10 \mathrm{~cm}$ soil core).

of the facility. The results indicate a much lower mobility than that of uranium.

The study of the activity ratios between radionuclides belonging to the uranium series provides information about the relative mobility of these radionuclides. In this sense we observed the greatest mobility to correspond to the uranium isotopes, with the thorium isotope being the least mobile. At the point most influenced by the installation, there was a high activity concentration of ${ }^{230} \mathrm{Th}$ in the surface layer. This activity concentration rapidly fell off to the values of uninfluenced points, indicating the low mobility in depth of this radionuclide. In contrast, at this same point the uranium isotopes reached a depth of at least $40 \mathrm{~cm}$. In general, the natural radionuclides presented little migration in depth, with the maximum depth achieved being by uranium isotopes, such as was seen in the case of ${ }^{238} \mathrm{U}$ at $40 \mathrm{~cm}$ at the point most influenced by the installation, which had a greater activity concentration than the same depth for soils not influenced by the mine.

\section{Acknowledgments}

Thanks are due to the Ministerio de Ciencia e Innovación, Dirección General de Investigación y Gestión del Plan Nacional de I+D+I (CTM2009-07785 project), the Fondo Social Europeo de Desarrollo Regional (FEDER), and 
the Junta de Castilla y León (GR12 project) for financial support. We also acknowledge financial support from the Empresa Nacional de Resíduos Radiactivos (ENRESA), the Spanish National Agency for Radioactive Management (project 0078000102).

\section{References}

[1] BLANCO RODRÍGUEZ P. et al., Sci. Total Environ. 284 (2002) 167.

[2] LOZANO J. C., J. Environ. Radioactiv. 63 (2002) 153.

[3] VERA TOMÉ F., J. Environ. Radioactiv 59 (2002) 41.

[4] JIANG F. S. et al., J. Radioanal. Nucl. Chem. 100 (1986) 65.

[5] VERA TOMÉ F. et al., Nucl. Instrum. Methods Phys. Res. A348 (1994) 183.

[6] BLANCO P. et al., Appl. Radiat. Isotopes 57 (2002) 785.

[7] BLANCO P. et al., Appl. Radiat. Isotopes 60 (2004) 83. 